\title{
Research Article: A study on problems faced by anganwadi workers and suggestions given by them
}

\author{
GOURI G. YELVATTIMATH* AND D. A. NITHYASHREE
}

Article Chronicle : Received : 14.04.2014;

Revised : 03.01.2015; Accepted : 17.01.2015

KeY Words : Anganwadi, ICDS (Integrated child development services), Pre-school

\section{Author for correspondence :}

\section{GOURI G.}

\section{YELVATTIMATH}

Department of Extension and Communication Management, College of Rural Home Science, University of Agricultural Sciences, DHARWAD (KARNATAKA) INDIA Email:y.gouri6@ gmail.com

See end of the article for authors' affiliations
SUMMARY : To analyse the socio- personal characteristics and to list out the problems faced by Aganwadi workers and suggestions given by the Aganwadi workers, a study was conducted with radomon sampling. The functioning of Aganwadi workers was assessed by interviewing for their literacy status, years of experience, problems and suggestions. Results revealed that most of the Aganwadi workers were middle aged (60.92\%), high school level of education (46.36\%), 73.63 per cent were married, 33.63 per cent of the total sample were with less than five years experience and between five to ten years. Most of the Anganwadi workers complained that they had no time to conduct pre-school education $(89.45 \%)$, and 78 per cent suggested to fix the timings for pre-school activities.

How to cite this article : Yelvattimath, Gouri G. and Nithyashree, D. A. (2015). A study on problems faced by anganwadi workers and suggestions given by them. Agric. Update, 10(1): 40-43. 